Article

\title{
Wheat Response to No-Tillage and Nitrogen Fertilization in a Long-Term Faba Bean-Based Rotation
}

\author{
Salem Alhajj Ali, Luigi Tedone, Leonardo Verdini, Eugenio Cazzato *(D) and \\ Giuseppe De Mastro
}

Department of Agricultural and Environmental Science, University of Bari Aldo Moro, Via Amendola 165/A-, 70126 Bari, Italy; salem_grb@yahoo.com (S.A.A.); luigi.tedone@uniba.it (L.T.); leonardo.verdini@uniba.it (L.V.); giuseppe.demastro@uniba.it (G.D.M.)

* Correspondence: eugenio.cazzato@uniba.it; Tel.: +39-080-544-2973

Received: 11 January 2019; Accepted: 23 January 2019; Published: 26 January 2019

\begin{abstract}
A field experiment was conducted in Southern Italy to study the response of durum wheat (Triticum turgidum L. var. durum) grain yield and quality traits to a no-tillage (NT) system and different nitrogen $\mathrm{N}$ fertilizer rates $\left(30,60\right.$, and $\left.90 \mathrm{~kg} \mathrm{~N} \mathrm{ha}^{-1}\right)$. The NT system was evaluated and compared to conventional (CT) and reduced (RT) tillage within continuous wheat (WW) and faba bean-wheat (FW) crop sequences over 3-years (2010-2012). The results showed a promising grain yield increase $(30 \%)$ in the last year. The effect of the $\mathrm{N}$ rate on protein content was significant, while productive parameters were not significantly influenced due to both weather conditions and the previous crop. Tillage effect was significantly $(p \leq 0.05)$ positive on grain yield, yield components and quality parameters, especially in NT system, and was more pronounced when accompanied with faba bean in the rotation system. Despite producing a lower grain protein content $(13 \%)$ compared to other systems, NT produced good semolina quality (with higher hectoliter weight and lower percentage of broken and shriveled grains). This study provides useful information for farmers on how to produce a satisfactory yield and good grain quality with minimum inputs, helping to design sustainable strategies for durum wheat cultivation in the dry regions.
\end{abstract}

Keywords: Triticum turgidum; grain quality; conservation practices; $\mathrm{N}$ rates; crop rotation

\section{Introduction}

Durum wheat is widely cultivated in the Mediterranean, under rainfed conditions using conventional tillage (CT) and high input of synthetic $\mathrm{N}$ fertilizers. In Italy, durum wheat is important for the economy by providing the semolina to produce pasta, being Italy the largest supplier and exporter in the world [1]. Since more than two thirds of durum wheat production comes from the Italian southern regions [2], cropping strategies that optimize input use and increase the efficiency of fertilizers must be developed, especially in the dry regions. One of the recently adopted strategies in rainfed durum wheat production is conservation practices. The adoption of these practices in wheat production is believed to have positive results in terms of crop productivity and grain quality, and safeguarding of the environment. Important factors of conservation agriculture include: minimum soil disturbance, maintenance of soil cover and crop rotations [3], which have been proposed to improve the efficiency of agricultural systems. Several studies have found that conservation agriculture practices enhance grain yield, ensure a good level of grain quality [4], save energy [5], and lower environmental impacts [6]. Since nitrogen (N) is an important element in agriculture, the application of $\mathrm{N}$ fertilizer is fundamental for crop production, especially in wheat. Current research efforts, however, are trying 
to reduce the use of $\mathrm{N}$ fertilizer to avoid unfavorable environmental consequences due to its losses without affecting crop productivity. A visible strategy in this regard is based on the reduction of $\mathrm{N}$ fertilizer requirements in cropping systems through the introduction of legume crops either in a rotation [7] or intercropping [8]. Several studies have reported the effect of legume crops on the yield of subsequent crops in the rotation $[7,9,10]$. Bedoussac and Justes [8] have found that wheat grain protein concentration was significantly higher in durum wheat-winter pea intercrop than in sole crops because of more $\mathrm{N}$ was remobilized into wheat grain due to the high pea $\mathrm{N}_{2}$ fixation rate in intercrops. Although the effect of $\mathrm{N}$ fertilizer on crop production has been widely investigated, the direct effect on wheat yield and/or quality in legume-based rotation is not well established. Galantini et al. [11] found that increasing $\mathrm{N}$ fertilizer rates improve grain protein with little effect on grain yield due to the effect of rotation with legumes. Lòpez-Bellido et al. [12] linked the effect of $\mathrm{N}$ on grain yield and quality to the rainfall in the growing season and found that the $\mathrm{N}$ rate influenced wheat yield when rainfall exceeded $450 \mathrm{~mm}$ in the growing season.

The tillage system represents another strategy in wheat production due to the influence on the physical, chemical, and biological properties of soil. Conservation management practices, including minimum/no-tillage, a high crop residue return, and crop rotation [13], can increase crop productivity due to the enhancement in soil structure and fertility [4]. Lòpez-Bellido et al. [12] found that continuous conservation tillage is a viable alternative to intensive tillage in terms of wheat production and quality. These soil management practices are mainly adopted in North and Latin America, but they are becoming increasingly popular in Australia, China, and, more gradually, in Europe [14]. Despite the documented benefits [15-21], conservation tillage systems are only practiced on approximately $2 \%$ of total cropland in the Mediterranean area [22]. Previous studies have evaluated the effect of tillage system on wheat grain yield and/or quality in Italy [4,23-27] and other Mediterranean areas [28-31]. Nevertheless, their findings vary considerably due to differences in soil type, soil moisture, climate conditions, and cropping system. A recent study by Ruisi et al. [14] reported that NT performed better under water stress during the crop cycle, whereas CT led to higher yields when water was adequate. Moreover, the tillage method and rotation with legumes can affect grain yield, and positively influence the wheat protein content [32-34]. The grain quality is highly dependent on the protein content in grain [35]. Grain quality depends on many factors, including crop rotation [12,36,37].

Therefore, the aim of this study was to test and to confirm the sustainability of conservation management practices in durum wheat cultivation in the dry areas. In particular, the field trial was conducted to test the effect of conservation tillage technique and reduction of $\mathrm{N}$ fertilizer rate, through the introduction of a legume crop, on wheat grain yield and quality.

\section{Materials and Methods}

\subsection{Site Description}

The site was a typical Mediterranean area in southern Italy, located in Policoro (MT) $\left(40^{\circ} 10^{\prime} 20^{\prime \prime}\right.$ $\mathrm{N}, 16^{\circ} 39^{\prime} 04^{\prime \prime} \mathrm{E}$ ) and site is at $15 \mathrm{~m}$ above sea level, characterized by a sub-arid climate. For the three years, daily weather data were obtained from a meteorological station located within $300 \mathrm{~m}$ from the experimental field. The temperature is typical of the Mediterranean climate whereas the average annual rainfall is about $560 \mathrm{~mm}$ distributed mainly during autumn and winter. The surface soil texture is loamy (sand, $39.78 \%$; silt, $37.40 \%$; clay, 22.28\%) according to the USDA classification system. Additional soil features are reported in Table 1. 
Table 1. Soil physico-chemical properties of the experimental site.

\begin{tabular}{ccc}
\hline Characteristics & Unit & Value \\
\hline Total N & $\%$ & 0.196 \\
$\mathrm{P}_{2} \mathrm{O}_{5}$ Assimilable & $\mathrm{ppm}$ & 40 \\
$\mathrm{NO}_{3}-\mathrm{N}$ & $\mathrm{ppm}$ & 14.3 \\
Amminium & $\mathrm{ppm}$ & trace \\
Organic Matter & $\%$ & 2.8 \\
Total Lime & $\%$ & 8.8 \\
pH & - & 7.72 \\
Sand & $\%$ & 39.78 \\
Silt & $\%$ & 37.40 \\
Clay & $\%$ & 22.82 \\
\hline
\end{tabular}

\subsection{Wheat Experimental Design}

A medium-term rotation experiment was established in the 2009-2010 growing season up to 2011-2012 to study the performance of rainfed durum wheat under high and low input farming systems. In this study, however, the medium-term response of wheat grain yield and quality to different input intensities was evaluated within a legume-based rotation system in a typical Mediterranean area over three years (one cycle of wheat and faba bean plus start-up year). Thus, durum wheat (Triticum turgidum L. var. durum cv Iride) was grown in rotation with faba bean (Vicia faba var. equina Pers. cv Prothabat 69) under rainfed conditions. The crop rotation was duplicated in two adjacent fields to enable both crops to be present each year $[25,38]$. Both wheat and faba bean fields were arranged in a split-plot design with three replicates. Within each main plot of wheat, treatments consisted of three $\mathrm{N}$ fertilizer rates $\left(30,60\right.$, and $90 \mathrm{~kg} \mathrm{~N}^{-1}$, and no $\mathrm{N}$ fertilizer treatment as control) and three tillage systems: conventional tillage (CT), reduced tillage (RT), and no-tillage (NT). The faba bean phase of the rotation received no $\mathrm{N}$ fertilizer, but the same level of soil disturbance. Based on the history of the experimental field, the different tillage systems were employed two years before the start of this experiment following the same level of soil disturbance under WW.

Both wheat and faba bean crops were sown in November and harvested in June each year. Sowing was affected using different sowing machines by opening a narrow slot. In the NT system, the crop was planted in unprepared soil using a sod-seeder (IGEA 2700 Semina Sodo, Gravina in Puglia, BA, Italy) to obtain the right seed coverage without soil preparation. In CT and RT, a conventional seed driller (LAROCCA 14 FALC) was used after essential soil disturbance had been performed. Wheat was sown at a rate of $200 \mathrm{~kg} \mathrm{ha}^{-1}$, whereas faba bean was sown at a rate of $180 \mathrm{~kg} \mathrm{ha}^{-1}$. N fertilizer was applied as urea $(46 \% \mathrm{~N})$ at the end of the tillering stage using a spinning fertilizer distributer. In the NT system, weeds were controlled before sowing by spraying glyphosate [N-(phosphonomethyl)-glycine] $\left(1.5 \mathrm{~L} \mathrm{ha}^{-1}\right)$, whereas GRANNSTAR (tribenuron methyl) herbicide was applied top-dress in the three tillage systems at the tillering stage.

\subsection{Wheat Biomass Yield}

Both wheat and faba bean fields were harvested in June each year for biomass production (grain and straw). A plot combine harvester (WINTERSTEIGER classic-1.4 m wide) was used. Given the size of each plot $\left(2450 \mathrm{~m}^{-2}\right)$, grain and straw yield data used in this study were the average of three harvesting times repeated following a linear pattern of $20 \mathrm{~m}$ in length around the center of each plot to obtain more accurate measures, and to avoid any border effect. For the analysis, the average of three harvesting times were used per plot. Wheat plant height and number of spikes per $\mathrm{m}^{-2}$ were determined. The number of spikes per unit area was estimated by counting heads along $50-\mathrm{cm}$ sections of two rows in each plot. 


\subsection{Wheat Grain Quality}

Wheat grains were cleaned using a dockage tester, then, protein content (\%) was determined using the NIR FOSS Infratec 1241-grain analyzer, while hectoliter weight $\left(\mathrm{kg} \mathrm{hL}^{-1}\right)$ and grain humidity (\%) were measured using the Agricultural Tester (Aquasearch 600). Broken and shriveled grains (\%), and piebald grains (\%) determination were carried out following the Official Grain Grading Guide from Canada [39].

\subsection{Soil Analysis}

Soil samples were taken around the center of each plot for each of the three different layers $(0-30$, 30-60, and 60-90 cm) using a manual Eijkelkamp auger. To correctly represent soil variability within a large field-scale, the sample points were organized into a systematic W-route sampling method. Total $\mathrm{N}$ was determined using Kjeldahl digestion. The analysis was performed at sowing in the base year and at post-harvest in the last year to study the change in $\mathrm{N}$ status as affected by treatments. Nitrate concentration was determined using a nitrate (NO3-) test kit (Spectroquant ${ }^{\circledR}$, Merck, Darmstadt, Germany). To evaluate the nutritional status and plant use of available N, soil was sampled twice per year (according to the Ministry of Agriculture and Forestry; G.U. 121 of 25/05/1992) for $\mathrm{NO}_{3}-\mathrm{N}$ determination; prior to $\mathrm{N}$ application (in early March at tillering stage) and after harvesting (in late July). Oven dry weight of soil samples at $105^{\circ} \mathrm{C}$ was determined after $24 \mathrm{~h}$ to measure the soil water content (SWC) (gravimetric water content, $\mathrm{mg}$ water $\mathrm{g}^{-1}$ dry soil, which was then converted into the percentage of water $\mathrm{g}^{-1}$ dry soil) of $30 \mathrm{~cm}$ layers in the top 0-90 $\mathrm{cm}$ soil profile at tillering and after harvesting [40]. Organic matter (OM) content was determined using the Walkley-Black method. Since organic matter formation and stability are largely related to long-term moisture and temperature trends, OM content was analyzed at the end of each growing season each year at two soil profiles $(0-30$ and $30-60 \mathrm{~cm})$.

\subsection{Land and Rainfall Use Efficiency}

The land use efficiency (LUE) index was calculated to evaluate the performance of different management systems in terms of yield production as a function of the area cultivated. The LUE was determined according to Quaye et al. [41]. For each growing season, rainfall use efficiency (RUE) was calculated to assess the capacity of the seasonal rainfall amount to produce adequate yield under different soil management systems, according to Gwenzi et al. [42] as follows:

$$
\text { RUE }\left(\mathrm{kg} \mathrm{ha}^{-1} \mathrm{~mm}^{-1}\right)=\mathrm{GY} / \mathrm{TSR}
$$

where: RUE = rainfall use efficiency ( $\mathrm{kg} / \mathrm{ha}$ of grain per $\mathrm{mm}$ of rainfall), GY = grain yield $(\mathrm{kg} / \mathrm{ha})$, and $\mathrm{TSR}=$ total seasonal rainfall $(\mathrm{mm})$.

\subsection{Statistical Analysis}

Data from the split-plot experiments were analyzed using SAS software [43]. For all parameters, the years were considered as a variable effect; tillage and $\mathrm{N}$ application were considered as a fixed effect. For the soil analysis, the depth was considered as a sub-factor. The analysis was done according to methodology described by Gomez and Gomez [44]. Means were compared using the LSD test at the $5 \%$ probability level.

\section{Results}

\subsection{Weather Conditions}

Monthly rainfall and temperature means at the experiment site are shown in Table 2 over the three growing seasons. The growing season of 2010-2011 was the wettest year $(528 \mathrm{~mm})$, followed by 2011-2012 (404 mm) and, finally, 2009-2010 (354 mm). Compared to the mean annual 
rainfall at the experimental site over the last 50 years (from 1959 to 2009) (472 mm), 2009-2010 was the driest year followed by 2011-2012, while 2010-2011 was slightly above the normal (Table 2). The meteorological data highlighted considerable differences in rainfall distribution among the three years. In 2009-2010, rainfall peaked from the end of winter dormancy/beginning of tillering to anthesis periods (January-May) exceeding the 50 -year average with $88.6 \%$ of the total rainfall during that season. However, some water shortages during plant establishment (November and December) were reported in this year compared to the 50-year average (Table 2).

During the 2010-2011 growing season, rainfall amount accounted for $81 \%$ of the total annual rainfall. Most of the rainfall during this growing season was recorded between tillering and stem elongation stages. The rainfall amount from 2010-2011 reached its peak during the tillering stage (especially in March), promoting wheat vegetative growth over grain yield. In 2011-2012, rainfall showed a good distribution during growth stages, which satisfied plant needs during the growing season. This rainfall distribution in the last year along with the nutrient stability in the wheat field led to a significant increase in biomass production compared to the first and the second seasons. Mean maximum temperatures throughout the growing season were higher in the 2009-2010 season and lower in the 2011-2012 season. Therefore, the first growing season (2009-2010) was the hottest and the driest with the lowest annual precipitation (Table 2). Consequently, grain yield in this season was influenced by the low water availability, especially in April (heading/flowering stage). In the 2010-2011 season, however, the abundant amount of rainfall in March lead to pathological problems, which affected productivity. During the 2011-2012 season, most rainfall was recorded between October to April and accounted for $92 \%$ of the total annual rainfall.

Table 2. Monthly rainfall and mean maximum $\left(T_{\max }\right)$ and minimum $\left(T_{\min }\right)$ temperatures for the three growing seasons (2009/2010-2011/2012) compared to long-term data (1959-2009).

\begin{tabular}{|c|c|c|c|c|c|c|c|c|c|c|c|c|}
\hline Month & \multicolumn{3}{|c|}{ 2009-2010 } & \multicolumn{3}{|c|}{ 2010-2011 } & \multicolumn{3}{|c|}{ 2011-2012 } & \multicolumn{3}{|c|}{ 50-year Mean } \\
\hline November & 6.9 & 19 & 8.6 & 51.8 & 20.2 & 11 & 63 & 19 & 10.9 & 77.3 & 19.2 & 6.8 \\
\hline December & 14.5 & 16.8 & 9.0 & 7.8 & 14.6 & 6.4 & 53.1 & 15.9 & 6.9 & 79.3 & 14.4 & 4.8 \\
\hline January & 91 & 14.3 & 6.8 & 71.6 & 12.7 & 5 & 67.1 & 13.5 & 4.5 & 67.7 & 12.8 & 3.8 \\
\hline April & 50.3 & 21.2 & 10.6 & 58.5 & 21.4 & 10.2 & 56.9 & 18.7 & 8.7 & 34.5 & 19.7 & 7.7 \\
\hline May & 32.8 & 24.4 & 14.9 & 26.1 & 24.3 & 14.1 & 22.7 & 23.7 & 11.9 & 29.3 & 25.2 & 11.4 \\
\hline June & 15.9 & 29.7 & 18.5 & 20 & 30.1 & 18.6 & 6.1 & 30.9 & 17.8 & 17.9 & 29.7 & 15.4 \\
\hline Total & 354 & & & 528 & & & 404.7 & & & 472 & & \\
\hline
\end{tabular}

\subsection{Grain Yield and Yield Components}

The overall results indicate a significant increase in average grain yield in the last year (Table 3). The results indicate that the tillage system had a significant $(p \leq 0.05)$ effect on grain yield during the three years, whereas the interaction between treatments was not significant except for year $x$ tillage (Table 3). In addition, there was an interaction effect of the yield response to tillage as a function of weather conditions, thus indicating that yield response to the NT system was more evident in the driest year. Indeed, the tillage effect on grain yield was more significant in the first year (2009-2010) when the rainfall was far below the normal average, thus indicating a great workability potential of the NT technique in dry areas. Considering the influence of the site-specific conditions, our findings indicate that durum wheat cultivation had the highest average yield $\left(5.8 \mathrm{tha}^{-1}\right)$ when conservation agriculture was applied using the NT system in southern Italy. This was significantly higher than CT $\left(5.1 \mathrm{t} \mathrm{ha}^{-1}\right)$, whereas RT produced the lowest grain yield with an average of $4.7 \mathrm{t} \mathrm{ha}^{-1}$ over the three years (Table 3). The table also highlights that the effect of the tillage system on grain yields in each individual year was confirmed with those obtained from the grain yield between years and was always in favor of the NT system. 
Table 3. Annual changes of wheat grain yield $\left(\mathrm{t} \mathrm{ha}^{-1}\right)$ as affected by the tillage method, $\mathrm{N}$ rate, and cropping system.

\begin{tabular}{|c|c|c|c|c|c|c|}
\hline \multirow{2}{*}{ Cropping Year $(\mathrm{Y})$} & \multirow{2}{*}{ Tillage (T) } & \multicolumn{4}{|c|}{ Nitrogen Rate $\left(\mathrm{kg} \mathrm{ha}^{-1} \mathrm{~N}\right)$} & \multirow{2}{*}{ Mean } \\
\hline & & Test & 30 & 60 & 90 & \\
\hline \multirow{3}{*}{ 2009-2010 (WW) } & $\mathrm{CT}$ & 4.3 & 4.0 & 3.7 & 3.7 & 3.9 \\
\hline & RT & 4.2 & 3.6 & 3.4 & 3.4 & 3.6 \\
\hline & NT & 4.7 & 5.9 & 5.3 & 5.1 & 5.5 \\
\hline \multirow[t]{2}{*}{ Mean } & & 4.4 & 4.5 & 4.1 & 4.1 & $4.3 \mathrm{c}$ \\
\hline & CT & 5.1 & 5.3 & 5.2 & 4.6 & 5.0 \\
\hline \multirow[t]{2}{*}{ 2010-2011 (FW) } & RT & 5.4 & 4.6 & 4.3 & 4.5 & 4.7 \\
\hline & NT & 5.2 & 4.8 & 5.5 & 5.8 & 5.3 \\
\hline \multirow[t]{2}{*}{ Mean } & & 5.2 & 4.9 & 5.0 & 5.0 & $5.0 \mathrm{~b}$ \\
\hline & $\mathrm{CT}$ & 6.3 & 6.3 & 6.7 & 6.4 & 6.5 \\
\hline \multirow[t]{2}{*}{ 2011-2012 (FW) } & RT & 6.6 & 6.1 & 5.7 & 5.2 & 5.9 \\
\hline & NT & 6.5 & 6.9 & 6.7 & 6.3 & 6.6 \\
\hline \multirow[t]{2}{*}{ Mean } & & 6.5 & 6.5 & 6.4 & 6.0 & $6.3 a$ \\
\hline & $\mathrm{CT}$ & 5.2 & 5.2 & 5.2 & 4.9 & 5.1 \\
\hline \multirow[t]{2}{*}{ Tillage mean } & RT & 5.4 & 4.8 & 4.5 & 4.4 & 4.7 \\
\hline & NT & 5.5 & 5.9 & 5.8 & 5.7 & 5.8 \\
\hline $\mathrm{N}$ rate mean & & $5.4 a$ & $5.3 a$ & $5.2 \mathrm{a}$ & $5.0 \mathrm{a}$ & 5.2 \\
\hline ANOVA & $\begin{array}{ll}\mathrm{Y} & \mathrm{T} \\
* * * & * * *\end{array}$ & $\begin{array}{l}\mathrm{N} \\
\mathrm{ns}\end{array}$ & $\begin{array}{c}\mathrm{N} \times \mathrm{T} \\
\mathrm{ns}\end{array}$ & $\begin{array}{c}\mathrm{N} \times \mathrm{Y} \\
\mathrm{ns}\end{array}$ & $\mathrm{Y} \times \underset{* *}{\mathrm{~T}}$ & $\begin{array}{c}\mathrm{Y} \times \mathrm{T} \times \mathrm{N} \\
\mathrm{ns}\end{array}$ \\
\hline
\end{tabular}

${ }^{*} p \leq 0.05,{ }^{* *} p \leq 0.01$, and ${ }^{* * *} p \leq 0.001 ; \mathrm{ns}=$ not significant; data followed by the same letter are not significantly different at $p \leq 0.05$ according to the LSD test.

The effect of the $\mathrm{N}$ rate on grain yield was not significant both in each individual year and on average across years as a whole (Table 3). We reported grain yield data as a function of the $\mathrm{N}$ rate $\left(0,30,60\right.$, and $\left.90 \mathrm{Kg} \mathrm{N} \mathrm{ha}^{-1}\right)$ to be 4.4, 4.5, 4.1, and 4.1; 5.2, 4.9, 5.0, and 5.0; 6.5, 6.5, 6.4, and 6.0 for the first, second, and the third growing season, respectively. The average of the three-year data had the same irregular trend with respect to the $\mathrm{N}$ rate and ranged between 5.4, 5.3, 5.2, and 5.0 in the 0 , 30,60 , and $90 \mathrm{~kg} \mathrm{~N} \mathrm{ha}^{-1}$ treatments, respectively. The interaction effect of the $\mathrm{N}$ rate $\times$ tillage was not significant; therefore, no regular tendency of grain yield was observed as a function of the $\mathrm{N}$ rate under the different tillage systems.

The effect of the cropping system, on the other hand, was significant (Table 3). The increase in grain yield, compared to the first year (wheat was grown after wheat), increased by $14 \%$ in the second year and doubled in the last year (30\%) when wheat was grown after faba bean. The interaction effect of year $x$ tillage was significant, indicating the tendency of the grain yield to increase under each tillage system towards the last year (Table 3).

The effect of treatments, as well as the interaction between them, on mean data over the 3-year on wheat yield component are reported in Table 4. On average, we found a value of $6.9 \mathrm{t} \mathrm{ha}^{-1}, 0.43$, $84.1 \mathrm{~cm}$, and 500.9 head $\mathrm{m}^{-2}$ for straw yield, HI, plant height, and number of heads $\mathrm{m}^{-2}$, respectively. The ANOVA showed that the effect of treatments on the investigated parameters varied between years, tillage system, and, in the case of HI, N rate, but with some exceptions. Straw yield was significantly affected by the cropping system and tillage, whereas the number of heads $\mathrm{m}^{-2}$ was affected only by the cropping system. The only significant effect due to the application of different $\mathrm{N}$ rates was on HI, which was also affected by the tillage system. The interaction effect on the investigated parameters was not significant except for the cropping year $\times$ tillage interaction on $\mathrm{HI}$ data. 


\subsection{Wheat Grain Quality}

Our data on quality revealed that both treatments (tillage and $\mathrm{N}$ rate) as well as cropping year had significant effects on quality parameters during the three years (Table 4). However, the interaction between them was not significant, except for year $\times$ tillage. The tillage method had a significant effect on all quality parameters. The analysis of grain quality highlighted that durum wheat cultivated under a conventional system generally reached the highest quality. The effect of the $\mathrm{N}$ rate was significant except for hectoliter weight and grain humidity; however, we found an acceptable grain quality under all the $\mathrm{N}$ rates despite the fact that the increase in the $\mathrm{N}$ rate favored the breaking of grains. Across years, the lowest grain quality was reported in the first year, however, a significant improvement in wheat grain quality was observed in the last year. The overall grain protein results indicate a positive correlation with the $\mathrm{N}$ rate, which was more pronounced under CT and in the wet years (2010-2011 and 2011-2012). No regular trend of a positive relationship was observed between the $\mathrm{N}$ rate and grain protein content in the NT system in the first growing season (2009-2010), the driest year. The NT system led also to a higher hectoliter weight value $\left(79.7 \mathrm{~kg} \mathrm{hL}^{-1} \mathrm{vs.} 77.0\right.$ and $76.5 \mathrm{~kg} \mathrm{hL}^{-1}$ in RT and $\mathrm{CT}$, respectively) and a lower broken and shriveled grain value (2.6\%) compared to 7.6 and $6.4 \%$ in RT and $\mathrm{CT}$, respectively, thus indicating a better grain filling, which increased the semolina extraction rate. Average hectoliter weight data showed that the differences due to the tillage effect were more significant between NT and the other systems (RT and CT), whereas no significant differences were found between RT and CT. Within years, average data showed the same trend, however, differences started to decrease in the last year (Table 4). Our results indicate a significant effect of the previous crop as the average value increased from 74.1 in the first year to 78.7 and 80.4 in the second and third years, respectively (Table 4).

The percentage of broken and shriveled grains as a whole was close to high quality durum wheat. The NT led to the best results in terms of premium durum wheat, whereas the percentage of broken and shriveled grains increased significantly with the increase in the $\mathrm{N}$ rate (Table 4). For the piebald grains, the percentage (7\%) was far below the quality standards for national standard durum wheat quality. The CT gave the lowest value compared to other systems, whereas the increase in the $\mathrm{N}$ rate lowered the percentage of piebald grains. Grain humidity was influenced by the tillage method and cropping system, whereas the $\mathrm{N}$ rate showed no effect on grain humidity. Within tillage methods, $\mathrm{CT}$ had the highest $(12.0 \%)$ grain humidity value, which was significantly higher that the values reported in RT and NT with 11.2 and $11.5 \%$, respectively. 
Table 4. Effect of tillage, $\mathrm{N}$ rate, and cropping system on durum wheat quality parameters, post-harvest soil water content (SWC), land use efficiency (LUE), and rainfall use efficiency (RUE).

\begin{tabular}{|c|c|c|c|c|c|c|c|c|c|c|c|c|}
\hline \multirow[b]{2}{*}{ Effect of Treatment } & \multicolumn{4}{|c|}{ Yield Component } & \multicolumn{5}{|c|}{ Quality Parameters } & \multirow[t]{2}{*}{ SWC (\%) } & \multirow[t]{2}{*}{$\begin{array}{c}\text { LUE } \\
\mathbf{m}^{-2} \mathbf{k g}^{-1}\end{array}$} & \multirow[t]{2}{*}{$\begin{array}{l}\text { RUE kg Grain } \\
\text { ha }^{-1} \mathrm{~mm}^{-1}\end{array}$} \\
\hline & $\begin{array}{l}\text { Straw } \\
\text { tha } \mathbf{a}^{-1}\end{array}$ & HI & $\begin{array}{c}\text { Plant } \\
\text { Height } \\
\mathrm{cm}\end{array}$ & $\begin{array}{l}\text { Spikes } \\
\mathrm{N} \mathrm{m}^{-2}\end{array}$ & $\begin{array}{l}\text { Protein } \\
(\%)\end{array}$ & $\begin{array}{c}\text { Hectolitre } \\
\text { Weight } \\
\left(\mathrm{kg} \mathrm{hL}^{-1}\right)\end{array}$ & $\begin{array}{c}\text { Broken and } \\
\text { Shriveled } \\
\text { Grains (\%) }\end{array}$ & $\begin{array}{c}\text { Piebald } \\
\text { Grains } \\
(\%)\end{array}$ & $\begin{array}{c}\text { Grain } \\
\text { Humidity } \\
(\%)\end{array}$ & & & \\
\hline Tillage (T) & $*$ & $* * *$ & ns & ns & $* * *$ & $* * *$ & $* * *$ & $* * *$ & $* *$ & * & $* *$ & $* * *$ \\
\hline CT & 7.3ab & $0.41 \mathrm{~b}$ & 84.3 & 488.7 & $14.9 \mathrm{a}$ & $76.5 \mathrm{~b}$ & $6.4 \mathrm{a}$ & $3.4 \mathrm{~b}$ & $12.0 \mathrm{a}$ & $16.9 a$ & $2.1 \mathrm{~b}$ & $12.2 \mathrm{~b}$ \\
\hline RT & $6.9 \mathrm{ab}$ & $0.41 \mathrm{~b}$ & 85.7 & 512.5 & $14.6 \mathrm{a}$ & $77.0 \mathrm{~b}$ & 7.6a & $3.5 b$ & $11.2 \mathrm{~b}$ & $16 \mathrm{~b}$ & $2.5 \mathrm{a}$ & $11.3 \mathrm{~b}$ \\
\hline NT & $6.6 \mathrm{~b}$ & $0.47 a$ & 82.2 & 501.4 & $13.0 \mathrm{~b}$ & $79.7 \mathrm{a}$ & $2.6 \mathrm{~b}$ & $14.1 \mathrm{a}$ & $11.5 \mathrm{~b}$ & $17.2 \mathrm{a}$ & $1.8 \mathrm{~b}$ & $13.7 \mathrm{a}$ \\
\hline Nitrogen rate $(\mathrm{N})$ & ns & $* * *$ & ns & ns & $* * *$ & ns & $* * *$ & $* * *$ & ns & $*$ & ns & ns \\
\hline 0 & 6.7 & $0.45 c$ & 82.6 & 473.3 & $13.3 \mathrm{~d}$ & 77.5 & $3.4 \mathrm{c}$ & $14.1 \mathrm{a}$ & 11.8 & $17.4 \mathrm{a}$ & 2.0 & 12.8 \\
\hline 30 & 6.8 & $0.44 b c$ & 82.6 & 480.1 & $14.1 \mathrm{c}$ & 77.5 & $4.9 \mathrm{~b}$ & $7.7 \mathrm{~b}$ & 11.5 & $17 \mathrm{ab}$ & 2.2 & 12.5 \\
\hline 60 & 7.0 & $0.42 \mathrm{ab}$ & 85.3 & 519.0 & $14.4 \mathrm{~b}$ & 77.1 & 6.4ab & $3.5 \mathrm{~b}$ & 11.4 & $16.5 \mathrm{ab}$ & 2.1 & 12.2 \\
\hline 90 & 7.2 & $0.41 \mathrm{a}$ & 84.8 & 531.1 & $14.8 \mathrm{a}$ & 79.0 & $7.5 \mathrm{a}$ & $2.6 \mathrm{~b}$ & 11.4 & $16 \mathrm{~b}$ & 2.2 & 12.0 \\
\hline Cropping year $(\mathrm{Y})$ & $* * *$ & ns & ns & $* * *$ & * & $* * *$ & ns & $* * *$ & $* * *$ & $* * *$ & $* * *$ & $* * *$ \\
\hline 2010-WW & $5.7 \mathrm{c}$ & 0.43 & 82.7 & $554.5 \mathrm{a}$ & $14.0 \mathrm{~b}$ & $74.1 \mathrm{c}$ & $5.4 \mathrm{a}$ & $12.8 \mathrm{a}$ & $12.6 \mathrm{a}$ & $23.15 a$ & $2.7 \mathrm{a}$ & $12.1 \mathrm{~b}$ \\
\hline 2011-FW & $6.5 \mathrm{~b}$ & 0.43 & 83.3 & $452.0 \mathrm{~b}$ & $14.4 \mathrm{a}$ & $78.7 \mathrm{~b}$ & $6.2 \mathrm{a}$ & $6.2 \mathrm{~b}$ & $11.0 \mathrm{~b}$ & $13.6 \mathrm{~b}$ & $2.1 \mathrm{~b}$ & $9.5 \mathrm{c}$ \\
\hline 2012-FW & $8.5 a$ & 0.42 & 86.3 & $496.1 \mathrm{~b}$ & 14.1ab & $80.4 a$ & $5.1 \mathrm{a}$ & $2.0 \mathrm{~b}$ & $10.0 \mathrm{c}$ & $13.4 \mathrm{~b}$ & $1.6 \mathrm{c}$ & $15.6 \mathrm{a}$ \\
\hline Mean & 6.9 & 0.43 & 84.1 & 500.9 & 14.2 & 77.8 & 5.5 & 7.0 & 11.5 & 16.7 & 2.1 & 12.4 \\
\hline \multicolumn{13}{|l|}{ Effect of interaction } \\
\hline $\mathrm{Y} \times \mathrm{T}$ & ns & $* * *$ & ns & ns & * & $* * *$ & $* *$ & ns & $* *$ & $* * *$ & * & * \\
\hline $\mathrm{Y} \times \mathrm{N}$ & ns & ns & ns & ns & ns & ns & ns & ns & ns & ns & ns & ns \\
\hline $\mathrm{T} \times \mathrm{N}$ & ns & ns & ns & ns & ns & ns & ns & ns & ns & ns & ns & ns \\
\hline $\mathrm{Y} \times \mathrm{T} \times \mathrm{N}$ & ns & ns & ns & ns & ns & ns & ns & ns & ns & ns & ns & ns \\
\hline
\end{tabular}

${ }^{*} p \leq 0.05,{ }^{* *} p \leq 0.01$ and ${ }^{* * *} p \leq 0.001, \mathrm{~ns}=$ not significant; data followed by the same letter are not significantly different at $p \leq 0.05$ significant level according to LSD test. 


\subsection{Rainfall Use Efficiency (RUE) and Land Use Efficiency (LUE)}

The ANOVA showed that RUE in wheat differs according to the soil management system and the cropping year (Table 4). The NT system had a significantly higher RUE $\left(13.7 \mathrm{~kg} \mathrm{ha}^{-1} \mathrm{~mm}^{-1}\right)$ than CT (12.2 $\left.\mathrm{kg} \mathrm{ha}^{-1} \mathrm{~mm}^{-1}\right)$ and RT (11.3 $\left.\mathrm{kg} \mathrm{ha}^{-1} \mathrm{~mm}^{-1}\right)$, indicating a good soil water-holding capacity in the NT system compared to the other systems. Across years, a significantly higher RUE (15.6 kg ha ${ }^{-1} \mathrm{~mm}^{-1}$ ) was reported in the last year (2012), whereas the second year had the lowest RUE with $9.5 \mathrm{~kg} \mathrm{ha}^{-1} \mathrm{~mm}^{-1}$ (Table 4) despite the highest amount of rainfall, which stimulated wheat vegetative growth over grain yield.

On average, $2.1 \mathrm{~m}^{-2}$ of arable land were used to produce $1 \mathrm{~kg}$ of rainfed durum wheat in southern Italy. Across treatments, our results indicate that the way the wheat was produced affects LUE. This was confirmed by ANOVA, which showed that LUE in wheat differs significantly according to the soil management system (varying between $2.5 \mathrm{~m}^{-2} \mathrm{~kg}^{-1}$ in RT to 2.1 and $1.8 \mathrm{~m}^{-2} \mathrm{~kg}^{-1}$ in CT and $\mathrm{NT}$, respectively) and to the cropping year (varying between $2.7 \mathrm{~m}^{-2} \mathrm{~kg}^{-1}$ in the first year to 2.1 and $1.6 \mathrm{~m}^{-2} \mathrm{~kg}^{-1}$ in the second and the third years, respectively) (Table 4). We found that the LUE results were linked to grain yield. Therefore, as in the case of grain yield, the $\mathrm{N}$ fertilizer rate had no significant effect on LUE data (2.0 and $2.2 \mathrm{~m}^{-2} \mathrm{~kg}^{-1}$ were reported in the control plot and the highest $\mathrm{N}$ rate plot, respectively). It was found that the arable land per unit of crop production showed an improved efficiency in land use under the NT soil management system and when wheat was grown after legumes (faba bean) (Table 4). The wheat grain yield obtained per unit of land was higher in the faba bean-wheat (FW) cropping system, especially in the last year. In addition, the interaction between cropping year and tillage system was also significant.

\subsection{Soil Management on Topsoil Quality}

The enhancement of soil conditions was more pronounced in the NT system (Figure 1), which resulted in higher grain yield. Organic matter was altered only slightly in the topsoil after the three years of NT treatment. The overall results indicate that, despite the low increase rate in OM content compared to the first year, NT showed an improvement in OM content $(p<0.05)$, particularly in the top $60 \mathrm{~cm}$ soil layer (Figure 1).

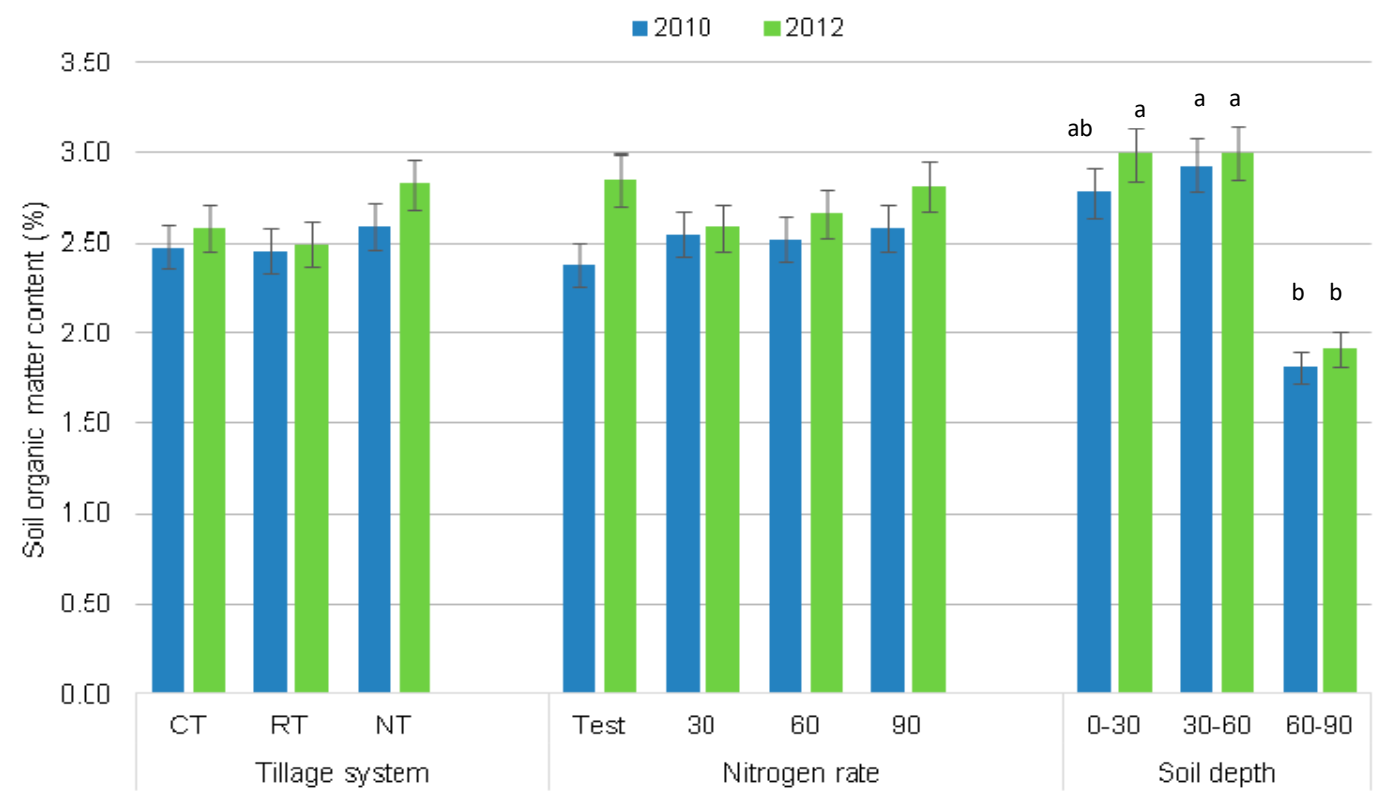

Figure 1. Changes in organic matter content in the soil after the last year (2011-2012) wheat harvesting compared to the base year (2009-2010) as affected by tillage (Conventional CT, Reduced RT), and No tillage NT), $\mathrm{N}$ fertilizer rate (Test $(0 \mathrm{~N}), 30,60$, and $\left.90 \mathrm{~kg} \mathrm{~N} \mathrm{ha}^{-1}\right)$, and different soil depths (0-30, 30-60, and 60-90 cm). a,b: Different letters indicate significant differences $(p<0.05)$. 
Figure 2 shows the variation of the total soil $\mathrm{N}$ content as affected by the tillage system, $\mathrm{N}$ rates, and different soil profiles. Across treatments, $\mathrm{N}$ content was significantly higher $(+26 \% ; p<0.05)$ in the last year compared to the analysis in the base year $(0.202 \%$ vs. $0.149 \%)$.

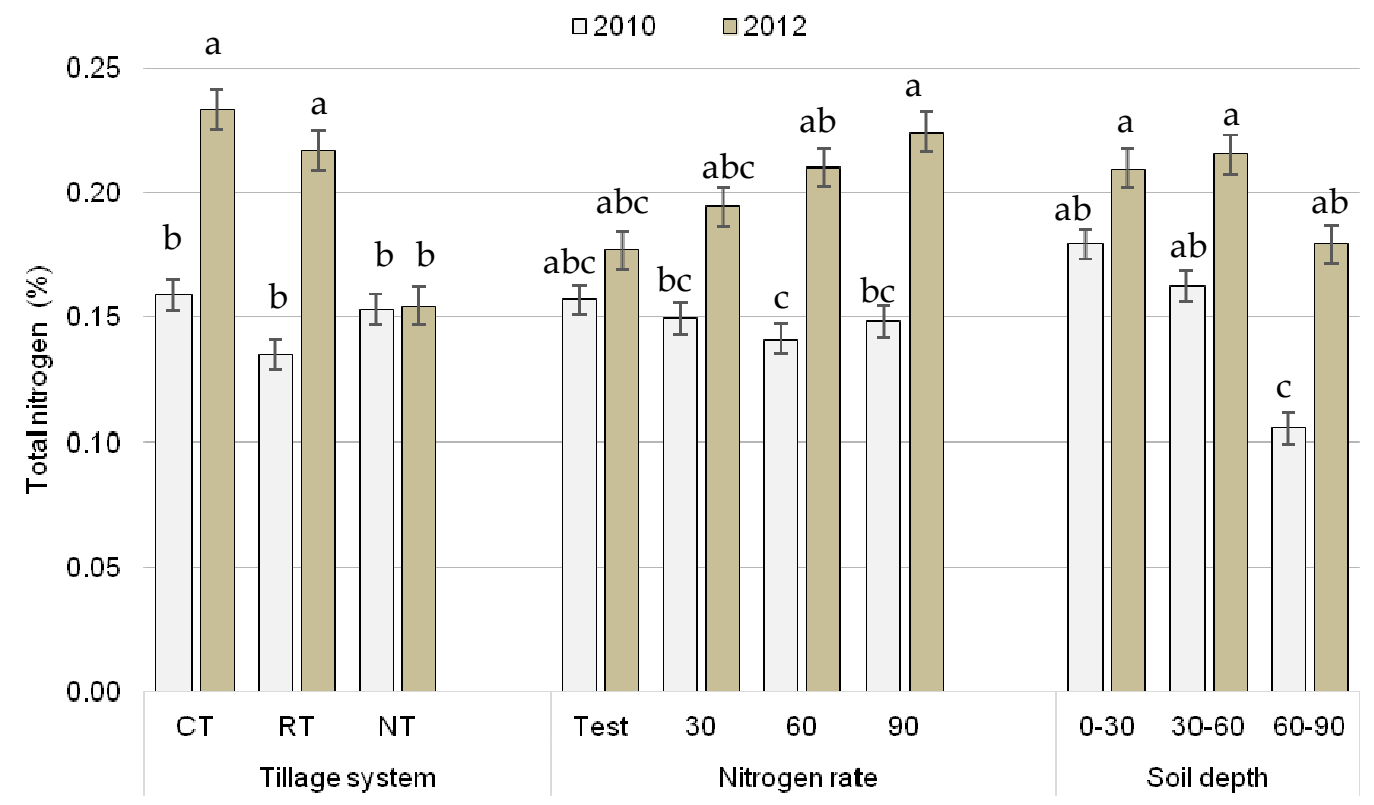

Figure 2. Total nitrogen in wheat soil after harvesting. Third season (2011-2012) is compared to first season (2009-2010); 30, 60, and 90 are the $\mathrm{N}$ fertilizer rates, while 30 (0-30), 60 (30-60), and 90 (60-90) are the soil profiles in centimeter. a-c: Different letters indicate significant differences $(p<0.05)$.

On average, $\mathrm{N}$ content was higher in $\mathrm{CT}$ and lower in NT, with a positive correlation to the $\mathrm{N}$ fertilizer rate and was higher $(p<0.05)$ in the first soil layer $(0-30 \mathrm{~cm})$ compared to the deep layers (Figure 2). Since plants normally use $\mathrm{N}$ in only ammonium and nitrate forms, the soil nitrate concentration was measured and reported after crop harvest. The three years mean nitrate-nitrogen $\left(\mathrm{NO}_{3}-\mathrm{N}\right)$ concentration in the soil is reported in Table 5 . The $\mathrm{NO}_{3}-\mathrm{N}$ level was significantly higher when faba bean was the preceding crop and lower when the preceding crop was wheat, regardless of the soil depth (Table 5). Differences in $\mathrm{NO}_{3}-\mathrm{N}$ concentration averaged between $12.5 \mathrm{mg} \mathrm{kg}^{-1}$ of dry soil in the WW cropping system in the first year to 69.3 and $59.9 \mathrm{mg} \mathrm{kg}^{-1}$ of dry soil in the FW cropping system in the second and third years, respectively.

\section{Discussion}

\subsection{Effect of Weather Conditions on Crop Productivity}

Because durum wheat cultivation in southern Italy is predominantly rainfed, precipitation and mean ambient temperatures are the most important climatic factors that affect its productivity. In the present study, the differences in grain yield between the three years were likely due to the more favorable rainfall distribution pattern, especially in the last year. Instead, the unfavorable and intense rainfall distribution in the second year led to some disease infestation (data not present), which, therefore, affected crop yield. In the first year, the lack of sufficient water during plant establishment along with relatively high temperatures (in comparison to the mean 50-year temperatures explained the lower plant development and, therefore, productivity. Further, in this study, the tillage system was the key factor influencing productive parameters in individual years and over the three years as a whole. Our findings are in agreement with Quaye et al. [41] and Santín-Montanyá et al. [45]

In our study, the good rainfall distribution during wheat development stages in 2011-2012 led to good water availability for the plant, especially from April to May. The water availability in this 
season resulted in higher grain yield compared to the other two seasons. De Vita et al. [4] reported a direct relationship between grain yield and the amount of rainfall during the vegetative period in wheat cultivation in southern Italy. In addition, the ability of the conservation tillage system to hold the water, especially in the dry season, indicating a good soil water-holding capacity in the NT system compared to the other systems, in agreement with the findings of Santín-Montanyá et al. [45] in wheat production. Yu et al. [46] also explained that the improvements in soil water-holding capacity and water use efficiency in NT are due to decreased soil bulk density, increased soil porosity, and the formation of soil water-stable aggregates, thus promoting crop yield.

\subsection{Effect of Main Treatments on Durum Wheat Production}

\subsubsection{Effect of Tillage System}

We tested the hypothesis of whether NT system can be a profitable alternative to CT practices in rainfed wheat production. The positive effect of NT on grain yield reported in the present study was in agreement with several studies [4,47]. Moreover, Troccoli et al. [48] reported that when NT is combined with residue retention and crop rotation, it could result in increasing rainfed crop productivity, especially in dry climates. Other studies [49], however, have reported a grain yield reduction under NT soil management. However, the biochemical mechanism underlying the increase or reduction in grain yield under the NT system has not yet been well explained. Explanations of the yield increase under the NT system in wheat production include the enhancement of the soil's water-holding capacity [46], especially under dry conditions [50]. In this context, the probable reason for the yield compensation in this study was to some extent the soil water conservation. In southern Italy, De Vita et al. [4] indicated that higher soil water content under NT guaranteed early and more uniform emergence compared to other systems, which can result in a higher grain yield. Our findings on SWC indicated a higher water availability in NT compared to other systems. This is in agreement with the findings of Sharma et al. [50] in rainfed wheat production in India and with the recent findings of Santín-Montanyá et al. [45] in wheat production in central Spain. The favored root systems (density and biomass at depth) and therefore grain yield of cereal in the NT system was confirmed by Plaza-Bonilla et al. [51] in dryland Mediterranean conditions. Further, Chakraborty et al. [52], found that the positive correlation between the rooting system and yield involved not only the amount, but also the spatial enlargement of a root system.

\subsubsection{Effects of N Fertilizer Rate}

Data from our study site indicate that the application of the full dose of $\mathrm{N}$ fertilizer at tillering had no significant effect on wheat grain yield regardless of the application rate in agreement with Jan et al. [53]. We believe that the reasons for the no yield response to different $\mathrm{N}$ rates was the effect of different factors, including rainfall amount and distribution, and the enhancement of soil nutritional status due to the rotation with the legume crop. Another important reason was due to the lodging effect, which was found to increase with the increase in the $\mathrm{N}$ rate (data not present). In addition, Rial-Lovera et al. [54] did not find any significant effect of $\mathrm{N}$ fertilization in the first year of spring wheat cultivation in UK. The direct effects of $\mathrm{N}$ fertilizer application on crop yield within a rotation system, with and without grain legumes, have shown that $\mathrm{N}$ fertilizer alone was unable to produce the same yield after non-leguminous pre-crops as after faba bean [55]. Furthermore, Garrido-Lestache et al. [56] found that $\mathrm{N}$ fertilizer had a greater effect on wheat quality indices than on grain yield. In our study, compared to the first year, the moderate-to-high $\mathrm{NO}_{3}-\mathrm{N}$ concentration at tillering and total soil $\mathrm{N}$ (Figure 2) in the soils of wheat fields reduced the potential for positive yield responses to $\mathrm{N}$ fertilizer. 
Table 5. Post-harvest soil $\mathrm{NO}_{3}-\mathrm{N}$ concentration ( $\mathrm{mg} \mathrm{kg}^{-1}$ of dry soil) as affected by tillage regime, soil depth, and cropping year.

\begin{tabular}{|c|c|c|c|c|c|c|}
\hline \multicolumn{2}{|c|}{ Treatments * } & \multirow{2}{*}{$\begin{array}{c}\text { Test } \\
39.6\end{array}$} & \multirow{2}{*}{$\begin{array}{c}30 \\
43.6\end{array}$} & \multirow{2}{*}{$\begin{array}{c}\mathbf{6 0} \\
47.9\end{array}$} & \multirow{2}{*}{$\begin{array}{c}90 \\
45.2\end{array}$} & \multirow{2}{*}{$\frac{\text { Mean }}{44.0 \mathrm{a}}$} \\
\hline \multirow{3}{*}{ Tillage } & $\mathrm{CT}$ & & & & & \\
\hline & RT & 31.9 & 33.3 & 54.5 & 42.1 & $40.5 a$ \\
\hline & NT & 19.2 & 21.5 & 28.2 & 25.5 & $23.6 \mathrm{~b}$ \\
\hline \multirow{3}{*}{$\begin{array}{l}\text { Soil Depth } \\
\quad(\mathrm{cm})\end{array}$} & $0-30$ & 43.3 & 47.0 & 61.7 & 54.5 & $51.7 \mathrm{a}$ \\
\hline & $30-60$ & 25.8 & 29.9 & 32.6 & 34.0 & $30.6 b$ \\
\hline & $60-90$ & 21.2 & 21.4 & 35.7 & 24.4 & $25.7 \mathrm{~b}$ \\
\hline \multirow{3}{*}{ Year } & 1st year (WW) & 15.3 & 19.4 & 22.8 & 20.7 & $19.5 c$ \\
\hline & 2nd year $(\mathrm{FW})$ & 38.4 & 34.2 & 44.6 & 44.2 & $40.3 b$ \\
\hline & 3rd year (FW) & 37.2 & 44.7 & 63.0 & 48.0 & $48.2 \mathrm{a}$ \\
\hline \multicolumn{2}{|c|}{ Mean } & $30.2 b$ & $32.8 \mathrm{~b}$ & $43.5 a$ & $37.6 \mathrm{ab}$ & 36.0 \\
\hline
\end{tabular}

$* 30,60$, and 90 are the $\mathrm{N}$ fertilizer rate in $\mathrm{kg} \mathrm{ha}^{-1}$; data followed by the same letter are not significantly different at $p \leq 0.05$ (LSD test); WW is referred to wheat grown after wheat while FW referred to wheat grown after faba bean.

In line with our findings, Abad et al. [57] found that in soils with low $\mathrm{N}$ content, the response to $\mathrm{N}$ fertilization was significant, whereas in soils with a high soil $\mathrm{N}$ content, there was no response to $\mathrm{N}$ fertilization. Similarly, Khakbazan et al. [58] found a low yield response to $\mathrm{N}$ application due to the relatively high residual soil $\mathrm{N}$ present at the initiation of the study. Jensen et al. [59] found that the grain yield of faba bean and cereal intercrops without $\mathrm{N}$ fertilizer was similar to the grain yield of the sole crop cereal fertilized with an optimal amount of $\mathrm{N}$ fertilizer.

\subsubsection{Effect of Cropping System}

In our study, on average, grain yield increased by about $32 \%$ in the last year when the FW cropping system was implemented, compared to the WW cropping system in the base year. This was in line with Ruisi et al. [27], who found that the NT system had a detrimental effect on wheat productivity in continuous wheat (WW), but improved yields in wheat-faba bean rotation compared to the CT system. Further, Amato et al. [60] found that when wheat was grown continuously, the adoption of NT resulted in a progressive decrease in grain yield compared with $\mathrm{CT}$, mainly due to a decrease in soil $\mathrm{N}$ availability. The rate of increase in grain yield in our study ranged between $0.7 \mathrm{t} \mathrm{ha}^{-1}$ in the second year to $2.0 \mathrm{t} \mathrm{ha}^{-1}$ in the last year compared to the base year $\left(1.3 \mathrm{tha}^{-1}\right.$ yield increase rate between the second and the third year). However, this increase in grain yield was almost always at the expense of grain quality. Farmers in Europe have estimated the pre-crop effects, ranging from 0.6 to $0.9 \mathrm{t} \mathrm{ha}^{-1}$ grain yield of wheat after grain legumes compared with wheat after cereals [61]. In this study, the effect of the preceding crop was reflected on grain yield and can be explained by the amount of available $\mathrm{N}$ in the soil (Figure 2). In fact, the improvement in soil quality in the FW cropping system resulted in a higher yield where most of the available $\mathrm{N}$ was used for grain and/or straw production. Kopke and Nemecek [55] highlighted the positive effect of faba bean, which can be quantified by yields of subsequent non-legumes compared to yields that follow non-leguminous reference crops. However, a positive yield response to the preceding legume crop can be influenced by many factors, including the lack of other nutrients, impacts on soil organisms through the effect of the mineralization process, and the availability of $\mathrm{N}$ form that can be absorbed by the plant, soil water and its influence on soil microorganism activities and nutrient mobility and soil structure.

\subsection{Analysis of Wheat Quality Parameters}

The various quality parameters of durum wheat obtained in this study were compared to the national standard commodity classification (http:/ / web.bmti.it/flex/cm/pages/ServeBLOB.php/L/ EN/IDPagina/132) for durum wheat in southern Italy. According to the national standard, wheat grain quality was classified into three grades with decreasing values: premium, high quality and 
standard. The overall results on different wheat quality parameters showed a higher frequency of values that ranged between premium and high-quality durum wheat. Since the quality of durum wheat grain is highly dependent on the protein content [62], our wheat grain can be classified as premium quality durum wheat However, several studies [63] have indicated that grain yield and grain protein content are often negatively correlated. Based on the analysis of grain protein data, we found some variation on grain yield, especially in the second and third years as a whole. We assume that the variability in protein content between the two seasons, as a function of the grain yield, was due to the effect of $\mathrm{N}$ dilution in the plant [12]. In addition, the temperature and rainfall amount during the growing season affected the grain protein content. Despite the lower grain yield, a good rainfall distribution during the grain filling stage resulted in a high protein content in the driest season (2009-2010). Abaye et al. [64] reported that drier and/or warmer conditions during the growing season enhanced the accumulation of higher grain protein. The effect of the $\mathrm{N}$ rate on protein content was significant and increased with the increase in the $\mathrm{N}$ rate, in agreement with other previous studies [65,66]. Ames et al. [67] also found that increasing $\mathrm{N}$ fertilizer resulted in an increased protein content. In our study, a significant effect on grain protein content was also found to be attributed to the different tillage systems. In particular, tilled soils (CT and RT) significantly increased grain protein content compared to NT soil. Lòpez-Bellido et al. [12] found significant differences in grain protein content between tillage systems, however, the effect was significant only in the last year of the 3-year study. The analysis of grain protein content revealed that grain protein content was higher when wheat was grown after an $\mathrm{N}$-fixing crop. This could be attributed to the higher $\mathrm{N}$ in the soil left over from the previous season, according to Bedoussac and Justes [8]. Although the $\mathrm{N}$ rate did not affect the hectoliter weight, the reported values under the different $\mathrm{N}$ rates fell within the high quality to premium durum wheat quality for the Italian market. This was in line with the findings of Lòpez-Bellido et al. [12] under Mediterranean conditions.

\subsection{Effect of Soil Management on Topsoil Quality}

The concentration of organic matter (OM) and total $\mathrm{N}$ are important for evaluating soil quality [47]. Based on our findings, when tillage aerates the soil, the rate of microbial decomposition of crop residues is increased, thus reducing soil OM. Grierson [68] found that with an adequate quantity of crop residues on the soil surface of NT plots, physical and chemical properties were maintained at favorable levels compared to tilled plots. Similarly, Mathew et al. [69] found that the role of crop residue accumulation on the soil surface of the NT system resulted in an enrichment of soil organic matter in the surface layer and, consequently, increased the abundance of microorganisms, thereby improving soil quality.

In our study, the improvement in soil properties was confirmed by the $\mathrm{NO}_{3}-\mathrm{N}$ content, which was significantly lower in the base year compared to the last year. The preceding crop affected the soil $\mathrm{NO}_{3}-\mathrm{N}$ content before wheat sowing in the second and the third year, in agreement with Ercoli et al. [70]. Soil $\mathrm{NO}_{3}-\mathrm{N}$ left after faba bean was doubled, resulting in higher $\mathrm{N}$ availability in the $0-30 \mathrm{~cm}$ profile. Similar to the total $\mathrm{N}$ content, the lower amount of $\mathrm{NO}_{3}-\mathrm{N}$ in the NT system compared to cultivated soils (CT and RT) improved the $\mathrm{N}$ availability to the crop through enhancement of the $\mathrm{N}_{2}$ fixation ability by faba bean. Doran [71] demonstrated that the $\mathrm{N}_{2}$ fixation by legume crops was increased in soils with low concentrations of $\mathrm{NO}_{3}-\mathrm{N}$. This was also confirmed by Hughes and Herridge [72], who found that reduced amounts of soil $\mathrm{NO}_{3}-\mathrm{N}$ in NT soil increased $\mathrm{N}_{2}$ fixation of soybeans. This could also account for the increase in $\mathrm{N}_{2}$ fixation in the $\mathrm{CT}$ treatment in our experiments, compared to RT. The production data confirmed these results, where the highest productivity was reported in the NT system and the lowest in RT.

The overall results on $\mathrm{NO}_{3}-\mathrm{N}$ levels indicate that the post-harvest $\mathrm{NO}_{3}-\mathrm{N}$ content in the soil was lower than at tillering (data not present). This was in line with Ercoli et al. [73], who analyzed $\mathrm{NO}_{3}-\mathrm{N}$ concentrations in durum wheat production in central Italy grown in the same soil type. The lower $\mathrm{NO}_{3}-\mathrm{N}$ concentration and total $\mathrm{N}$ content in NT soils indicated that much of the available nitrogen was used for grain and/or straw production and depended on weather conditions. From 
an environmental point of view, however, the gaseous loss of $\mathrm{N}$ is the dominant mechanism in an agricultural production system. Therefore, the higher $\mathrm{N}$ content in RT and CT soils can pose a potential threat to the environment through various loss processes, including volatilization, nitrification, and denitrification, which results in the release of greenhouse gases into the atmosphere and/or leaching to groundwater. In fact, our previous study [6] confirmed the higher environmental impact and GHG emissions in RT and CT compared to NT systems.

\section{Conclusions}

This study tested the sustainability of conservation agriculture techniques to overcome problems related to intensive agriculture for sustainable durum wheat production in the dry areas. Both the tillage system and previous crop had a significant impact on the grain yield and quality. However, this impact was influenced by weather conditions, especially the rainfall amount and distribution during the growing season. The $\mathrm{N}$ fertilizer rate showed no significant effect on grain yield; however, quality parameters were highly affected, particularly protein content. The overall results indicated that the implementation of CT and RT systems in wheat production in the dry areas of southern Italy tended to stimulate the vegetative growth of the plant over grain yield. On the other hand, the improvement in the water holding capacity in the NT system led to yield compensation over straw yield due to the higher water availability during the grain filling stage compared to other systems. Quality parameters under the NT system were within the range of standard values for premium durum wheat according to the national standard commodity classification of cereal in southern Italy. The NT technique could be a valuable alternative to $\mathrm{CT}$ in the dry areas of the Mediterranean region. However, for a better application of NT technique, it should be accompanied by an appropriate crop sequence as faba bean-wheat.

Author Contributions: Conceptualization, G.D.M. and S.A.A.; methodology, L.T. and S.A.A.; formal analysis, L.V. and L.T.; investigation, S.A.A. and L.V.; writing—original draft preparation, S.A.A. and E.C.; writing-review and editing, E.C.

Funding: This research received no external funding.

Acknowledgments: The Authors thank the technicians involved in this research.

Conflicts of Interest: The authors declare no conflict of interest.

\section{References}

1. Tedone, L.; Verdini, L.; Grassano, N.; Tarraf, W. De Mastro G. Optimizing nitrogen in order to improve the efficiency, eco-physiology, yield and quality on one cultivar of durum wheat. Ital. J. Agron. 2014, 9, 49-54. [CrossRef]

2. D'Egidio, M.G. Overview on pasta in the world. Tec. Molit. Int. 2007, 58, 92-97. [CrossRef]

3. Rautaray, S.K.; Mishra, A.; Verma, O.P. Energy efficiency, productivity and profitability of rice (Oryza sativa L.) based cropping systems for selected conservation practices. Arch. Agron. Soil Sci. 2017, 63, $1993-2006$. [CrossRef]

4. De Vita, P.; Di Paolo, E.; Fecondo, G.; Di Fonzo, N.; Pisante, M. No-tillage and conventional tillage effects on durum wheat yield, grain quality and soil moisture content in southern Italy. Soil Tillage Res. 2007, 92, 69-78. [CrossRef]

5. Alhajj Ali, S.; Tedone, L.; De Mastro, G. A compare on of the energy consumption of rainfed durum wheat under different management scenarios in southern Italy. Energy 2013, 61, 308-318. [CrossRef]

6. Alhajj Ali, S.; Tedone, L.; Verdini, L.; De Mastro, G. Effect of different crop management systems on rainfed durum wheat greenhouse gas emissions and carbon footprint under Mediterranean conditions. J. Clean. Prod. 2017, 140, 608-621. [CrossRef]

7. Peoples, M.B.; Brockwell, J.; Herridge, D.F.; Rochester, I.J.; Alves, B.J.R.; Urquiaga, S.; Boddey, R.M.; Dakora, F.D.; Bhattarai, S.; Maskey, S.L.; et al. The contributions of nitrogen-fixing crop legumes to the productivity of agricultural systems. Symbiosis 2009, 48, 1-17. [CrossRef] 
8. Bedoussac, L.; Justes, E. The efficiency of a durum wheat-winter pea intercrop to improve yield and wheat grain protein concentration depends on $\mathrm{N}$ availability during early growth. Plant Soil 2010, 330, 19-35. [CrossRef]

9. Nemecek, T.; von Richthofen, J.-S.; Dubois, G.; Casta, P.; Charles, R.; Pahl, H. Environmental impacts of introducing grain legumes into European crop rotations. Eur. J. Agron. 2008, 28, 380-393. [CrossRef]

10. Kirkegaard, J.A.; Christen, O.; Krupinsky, J.; Layzell, D. Break crop benefits in temperate wheat production. Field Crops Res. 2008, 107, 185-195. [CrossRef]

11. Galantini, J.A.; Landriscini, M.R.; Iglesias, J.O.; Miglierinac, A.M.; Rosell, R.A. The effects of crop rotation and fertilization on wheat productivity in the Pampean semiarid region of Argentina: 2. Nutrient balance, yield and grain quality. Soil Tillage Res. 2000, 53, 137-144. [CrossRef]

12. Lòpez-Bellido, L.; Fuentes, M.; Castillo, J.E.; Lopez-Garrido, F.J. Effects of tillage, crop rotation and nitrogen, fertilization on wheat-grain quality grown under rainfed Mediterranean conditions. Field Crops Res. 1998, 57, 265-276. [CrossRef]

13. Hobbs, P.R.; Sayre, K.; Gupta, R. The role of conservation agriculture in sustainable agriculture. Philos. Trans. R. Soc. B 2008, 363, 543-555. [CrossRef] [PubMed]

14. Ruisi, P.; Giambalvo, D.; Saia, S.; Di Miceli, G.; Frenda, A.S.; Plaia, A.; Amato, G. Conservation tillage in a semiarid Mediterranean environment: Results of 20 years of research. Ital. J. Agron. 2014, 9, 560. [CrossRef]

15. Uri, N.D.; Atwood, J.D.; Sanabria, J. The environment benefit and cost of conservation tillage. Environ. Geol. 1999, 38, 111-125. [CrossRef]

16. Kirkegaard, J.A. A review of trends in wheat yield responses to conservation cropping in Australia. Aust. J. Exp. Agric. 1995, 35, 835-848. [CrossRef]

17. Jordan, V.W.; Leake, A.R.; Ogilvy, S.E. Agronomic and environmental implications of soil management practices in integrated farming systems. Asp. Appl. Biol. 2000, 62, 61-66.

18. West, T.O.; Post, W.M. Soil organic carbon sequestration rates by tillage and crop rotation: A global data analysis. Soil Sci. Soc. Am. J. 2002, 66, 1930-1946. [CrossRef]

19. West, T.O.; Marland, G. A synthesis of carbon sequestration, carbon emissions, and net carbon flux in agriculture: Comparing tillage practices in the United States. Agric. Ecosyst. Environ. 2002, 91, 217-232. [CrossRef]

20. Madari, B.; Machado, P.L.O.A.; Torres, E.; De Andrade, A.G.; Valencia, L.I.O. No tillage and crop rotation effects on soil aggregation and organic carbon in a Rhodic Ferralsol from southern Brazil. Soil Tillage Res. 2005, 80, 185-200. [CrossRef]

21. Tabaglio, V.; Gavazzi, C.; Menta, C. The influence of no-till, conventional tillage and nitrogen fertilization on physico-chemical and biological indicators after three years of monoculture barley. Ital. J. Agron. 2008, 3, 233-240. [CrossRef]

22. FAO AQUASTAT. Database Query, FAO of the UN, Commissioned for the Exclusive Use of FAO-Conservation Agriculture. 2012. Available online: http://www.fao.org/nr/water/aquastat/data/ query / results (accessed on 10 November 2018).

23. De Sanctis, G.; Roggero, P.P.; Seddaiu, G.; Orsinic, R.; Porter, C.H.; Jones, J.W. Long-term no tillage increased soil organic carbon content of rain-fed cereal systems in a Mediterranean area. Eur. J. Agron. 2012, 40, $18-27$. [CrossRef]

24. Campiglia, E.; Mancinelli, R.; De Stefanis, E.; Pucciarmati, S.; Radicetti, E. The long-term effects of conventional and organic cropping systems, tillage managements and weather conditions on yield and grain quality of durum wheat (Triticum durum Desf.) in the Mediterranean environment of Central Italy. Field Crops Res. 2015, 176, 34-44. [CrossRef]

25. Seddaiu, G.; Iocola, I.; Farina, R.; Orsini, R.; Iezzi, G.; Roggero, P.P. Long-term effects of tillage practices and $\mathrm{N}$ fertilization in rainfed Mediterranean cropping systems: Durum wheat, sunflower and maize grain yield. Eur. J. Agron. 2016, 77, 166-178. [CrossRef]

26. Mazzoncini, M.; Antichi, D.; Di Benec, C.; Risaliti, R.; Petri, M.; Bonari, E. Soil carbon and nitrogen changes after 28 years of no-tillage management under Mediterranean conditions. Eur. J. Agron. 2016, 77, 156-165. [CrossRef]

27. Ruisi, P.; Saia, S.; Badagliacca, G.; Amato, G.; Frenda, A.S.; Giambalvo, D.; Di Miceli, G. Long-term effects of no tillage treatment on soil $\mathrm{N}$ availability, $\mathrm{N}$ uptake, and ${ }^{15} \mathrm{~N}$-fertilizer recovery of durum wheat differ in relation to crop sequence. Field Crops Res. 2016, 189, 51-58. [CrossRef] 
28. Hernanz, J.L.; Lopez, R.; Navarrete, L.; Sanchez-Giron, V. Long-term effects of tillage systems and rotations on soil structural stability and organic carbon stratification in semiarid central Spain. Soil Tillage Res. 2002, 66, 129-141. [CrossRef]

29. Al-Issa, T.A.; Samarah, N.H. Tillage practices in wheat production under rainfed conditions in Jordan: An economic comparison. World J. Agric. Sci. 2006, 2, 322-325.

30. Lòpez-Fando, C.; Dorado, J.; Pardo, M.T. Effects of zone-tillage in rotation with no-tillage on soil properties and crop yields in a semi-arid soil from central Spain. Soil Tillage Res. 2007, 95, 266-276. [CrossRef]

31. Munoz-Romero, V.; Benítez-Vega, J.; López-Bellido, L.; López-Bellido, R.J. Monitoring wheat root development in a rainfed vertisol: Tillage effect. Eur. J. Agron. 2010, 33, 182-187. [CrossRef]

32. Zentner, R.P.; Bowren, K.E.; Edwards, W.; Campbell, C.A. Effects of crop rotations and fertilization on yields and quality of spring wheat grown on a black Chernozem in north central Saskatchewan. Can. J. Plant Sci. 1990, 70, 383-397. [CrossRef]

33. Cox, D.J.; Shelton, D.R. Genotype-by-tillage interactions inhard red winter wheat quality evaluation. Agron. J. 1992, 84, 627-630. [CrossRef]

34. Borghi, B.; Giordani, G.; Corbellini, M.; Vaccino, P.; Guermandi, M.; Toderi, G. Influence of crop rotation, manure and fertilizers on bread making quality of wheat Triticum aestivum L. Eur. J. Agron. 1995, 4, 37-45. [CrossRef]

35. Stoddard, F.L.; Marshall, D.R. Variability in grain protein in Australian hexaploid wheats. Aust. J. Agric. Res. 1990, 41, 277-288. [CrossRef]

36. Dong, Z.; Layzell, D.B. Why do legume nodules evolve hydrogen gas? In Nitrogen Fixation: Global Perspectives, Proceedings of the 13th International Congress on Nitrogen Fixation, Hamilton, ON, Canada, 2-7 July 2001; Finan, T., O’Brian, M., Layzell, D., Vessey, K., Newton, W., Eds.; CABI Publ.: Hamilton, ON, Canada, 2002; pp. 331-335.

37. Golding, A.-L.; Zou, Y.; Yang, X.; Flynn, B.; Dong, Z. Plant growth promoting H2-oxidizing bacteria as seed inoculants for cereal crops. Agric. Sci. 2012, 3, 510-516. [CrossRef]

38. Cochran, W.G. Long-term agricultural experiments. Suppl. J. R. Stat. Soc. 1939, 6, 104-148. [CrossRef]

39. CGC (Canadian Grain Commission). Official Grain Grading Guide; Agriculture Edition: Winnipeg, MB, Canada, 2005; ISSN 1704-5118.

40. Gardner, W.H. Water content. In Methods of Soil Analysis, Part 1. Agronomy Monogr., 2nd ed.; Klute, A., Ed.; American Society of Agronomy—Soil Science Society of America: Madison, WI, USA, 1986; pp. $493-544$. [CrossRef]

41. Quaye, A.K.; Hall, C.A.S.; Luzadis, V.A. Agricultural land use efficiency and food crop production in Ghana. Environ. Dev. Sustain. 2010, 12, 967-983. [CrossRef]

42. Gwenzi, W.; Taru, M.; Mutema, Z.; Gotosa, J.; Mushiri, S.M. Tillage system and genotype effects on rainfed maize (Zea mays L.) productivity in semi-arid Zimbabwe. Afr. J. Agric. Res. 2008, 3, 101-110.

43. SAS Institute. SAS/STAT 9.2 User's Guide; SAS Inst.: Cary, NC, USA, 2008.

44. Gomez, K.A.; Gomez, A.A. Statistical Procedures for Agricultural Research; Wiley: New York, NY, USA, 1984.

45. Santín-Montanyá, M.I.; Fernández-Getino, A.P.; Zambrana, E.; Tenorio, J.L. Effects of tillage on winter wheat production in Mediterranean dryland fields. Arid Land Res. Manag. 2017, 1-14. [CrossRef]

46. Yu, H.Y.; Peng, W.Y.; Ma, X.; Zhang, K.L. Effects of no-tillage on soil water content and physical properties of spring corn fields in semiarid region of northern China. Ying Yong Sheng Tai Xue Bao 2011, 22, 99-104. (In Chinese with English abstract) [PubMed]

47. Shao, Y.; Xie, Y.; Wanga, C.; Yue, J.; Yao, Y.; Li, X.; Liu, W.; Zhu, Y.; Guo, T. Effects of different soil conservation tillage approaches on soil nutrients, water use and wheat-maize yield in rainfed dry-land regions of North China. Eur. J. Agron. 2016, 81, 37-45. [CrossRef]

48. Troccoli, A.; Maddaluno, C.; Mucci, M.; Russo, M.; Rinaldi, M. Is it appropriate to support the farmers for adopting conservation agriculture? Economic and environmental impact assessment. Ital. J. Agron. 2015, 10, 169-177. [CrossRef]

49. Xie, R.Z.; Li, S.K.; Jin, Y.Z.; Li, X.J.; Tang, Q.X.; Wang, K.R.; Gao, S.J. The trends of crop yield responses to conservation tillage in China. Sci. Agric. Sin. 2008, 41, 397-404. (In Chinese with English Abstract)

50. Sharma, K.L.; Grace, J.K.; Mishra, P.K.; Venkateswarlu, B.; Nagdeve, M.B.; Gabhane, V.V.; Sankar, G.M.; Korwar, G.R.; Chary, G.R.; Rao, C.S.; et al. Effect of Soil and Nutrient-Management Treatments on Soil Quality Indices under Cotton-Based Production System in Rainfed Semi-arid Tropical Vertisol. Commun. Soil Sci. Plant Anal. 2011, 42, 1298-1315. [CrossRef] 
51. Plaza-Bonilla, D.; Nolot, J.M.; Raffaillac, D.; Justes, E. Innovative cropping systems to reduce N inputs and maintain wheat yields by inserting grain legumes and cover crops in southwestern France. Eur. J. Agron. 2017, 82, 331-341. [CrossRef]

52. Chakraborty, D.; Nagarajan, S.; Aggarwal, P.; Gupta, V.K.; Tomar, R.K.; Garg, R.N.; Sahoo, R.N.; Sarkar, A.; Chopra, U.K.; Sarma, K.S.S.; et al. Effect of mulching on soil and plant water status, and the growth and yield of wheat (Triticum aestivum L.) in a semi-arid environment. Agric. Water Manag. 2008, 95, 1323-1334. [CrossRef]

53. Jan, M.; Khan, M.; Khan, A.; Arif, M.; Farhatullah Jan, D.; Saeed, M.; Afridi, M.Z. Improving wheat productivity through source and timing of nitrogen fertilization. Pak. J. Bot. 2011, 43, 905-914.

54. Rial-Lovera, K.; Davies, W.P.; Cannon, N.D.; Conway, J.S. Influence of tillage systems and nitrogen management on grain yield, grain protein and nitrogen-use efficiency in UK spring wheat. J. Agric. Sci. 2016, 154, 1437-1452. [CrossRef]

55. Kopke, U.; Nemecek, T. Ecological services of faba bean. Field Crops Res. 2010, 115, 217-233. [CrossRef]

56. Garrido-Lestache, E.; López-Bellido, R.J.; López-Bellido, L. Durum wheat quality under Mediterranean conditions as affected by $\mathrm{N}$ rate, timing and splitting, $\mathrm{N}$ form and $\mathrm{S}$ fertilization. Eur. J. Agron. 2005, 23, 265-278. [CrossRef]

57. Abad, A.; Michelena, A.; Lloveras, J. Effects of nitrogen supply on wheat and on soil nitrate. Agron. Sustain. Dev. 2005, 25, 439-446. [CrossRef]

58. Khakbazan, M.; Mohr, R.M.; Derksen, D.A.; Monreal, M.A.; Grant, C.A.; Zentner, R.P.; Moulin, A.P.; McLaren, D.L.; Irvine, R.B.; Nagy, C.N. Effects of alternative management practices on the economics, energy and GHG emissions of a wheat- pea cropping system in the Canadian prairies. Soil Tillage Res. 2009, 104, 30-38. [CrossRef]

59. Jensen, E.S.; Peoples, M.B.; Hauggaard-Nielsen, H. Faba bean in cropping systems. Field Crops Res. 2010, 115, 203-216. [CrossRef]

60. Amato, G.; Ruisi, P.; Frenda, A.S.; Di Miceli, G.; Saia, S.; Plaia, A.; Giambalvo, D. Long-term tillage and crop sequence effects on wheat grain yield and quality. Agron. J. 2013, 105, 1317-1327. [CrossRef]

61. Von Richthofen, J.-S.; Pahl, H.; Bouttet, D.; Casta, P.; Cartrysse, C.; Charles, R.; Lafarga, A. What do European farmers think about grain legumes? Grain Leg. 2006, 45, 14-15.

62. Gerba, L.; Getachew, B.; Walelign, W. Nitrogen fertilization effects on grain quality of durum wheat (Triticum turgidum L. var. durum) varieties in central Ethiopia. Agric. Sci. 2013, 4, 123. [CrossRef]

63. Feil, B. The inverse yield-protein relationship in cereals: Possibilities and limitations for genetically improving the grain protein yield. Trends Agron. 1997, 1, 103-119.

64. Abaye, A.O.; Brann, D.E.; Alley, M.M.; Griffey, C.A. Winter Durum Wheat: Do We Have All the Answers; Virginia Tech Publication: Petersburg, VA, USA, 1997; pp. 424-802.

65. Garrido-Lestache, E.; López-Bellido, R.J.; López-Bellido, L. Effect of N rate, timing and splitting and N type on bread-making quality in hard red spring wheat under rainfed Mediterranean conditions. Field Crops Res. 2004, 85, 213-236. [CrossRef]

66. Farrer, D.C.; Randy, W.; Ronnie, H.J.; Paul, M.; Jeffrey, G.W. Minimizing protein variability in soft red winter wheat: Impact of nitrogen application timing and rate. Agron. J. 2006, 98, 1137-1145. [CrossRef]

67. Ames, N.P.; Clarke, J.M.; Dexter, J.E.; Woods, S.M.; Selles, F.; Marchylo, B. Effects of nitrogen fertilizer on protein quantity and gluten strength parameters in durum wheat (Triticum turgidum L. var. durum) cultivars of variable Gluten strength. Cereal Chem. 2003, 80, 203-211. [CrossRef]

68. Grierson, I.T. Effects of varying tillage procedures on crop growth factors in southern Australia. In Proceedings of the 8th Conference of the International Soil Tillage Research Organization (ISTRO), Stuttgart, Gremany, 8-15 September 1979; University of Hohenheim: Stuttgart, Germany, 1979; Volume 1.

69. Mathew, R.P.; Feng, Y.; Githinji, L.; Ankumah, R.; Balkcom, K.S. Impact of No-Tillage and Conventional Tillage Systems on Soil Microbial Communities. Appl. Environ. Soil Sci. 2012, 2012, 548620. [CrossRef]

70. Ercoli, L.; Masoni, A.; Pampana, S.; Mariotti, M.; Arduini, I. The response of durum wheat to the preceding crop in a mediterranean environment. Sci. World J. 2014, 2014, 717562. [CrossRef] [PubMed]

71. Doran, J.W. Soil microbial and biochemical changes associated with reduced tillage. Soil Sci. Soc. Am. J. 1980, 44, 765-771. [CrossRef] 
72. Hughes, J.F.; Herridge, D.F. Effect of tillage on yield, nodulation and nitrogen fixation of soybeans in far north-coastal New South Wales. Aust. J. Exp. Agric. 1989, 29, 671-677. [CrossRef]

73. Ercoli, L.; Masoni, A.; Mariotti, M.; Pampana, S.; Pellegrino, E.; Arduini, I. Effect of preceding crop on the agronomic and economic performance of durum wheat in the transition from conventional to reduced tillage. Eur. J. Agron. 2017, 82, 125-133. [CrossRef] 